The author analyzes the exercise by the Commissioner of the Verkhovna Rada of Ukraine for Human Rights of control, administrative and jurisdictional powers in the field of ensuring compliance with legislation on personal data protection, as well as the powers to participate in the development of regulations in this area.

The criteria of independence of a state body in the exercise of its control powers, defined in international acts, are studied; an assessment of the institutional capacity of the Commissioner of the Verkhovna Rada of Ukraine for Human Rights in the field of state control over compliance with the legislation on personal data protection was conducted.

Based on the analysis, the expediency of establishing a separate independent supervisory body in the field of personal data protection, empowering it and ensuring a high degree of its independence, which will be consistent with the experience of some foreign countries and contribute to Ukraine's obligations under the Association Agreement. Ukraine, on the one hand, and the European Union, the European Atomic Energy Community and their Member States, on the other.

Keywords: personal data protection, state control, Verkhovna Rada Commissioner for Human Rights, institutional capacity.

DOI:10.33766/2524.0323.91.27-41

УДК 342.553(477)

\author{
С. О. Бутирін, \\ кандидат юридичних наук, \\ доцент кафедри теорії та філософії права \\ Одеського державного університету \\ внутрішніх справ \\ (м. Одеса, Україна) \\ e-mail:Butyrinevgenij83@gmail.com \\ iD ttps:/ / orcid.org/0000-0002-3915-4026
}

\title{
КОМПЕТЕНЦІЯ ОРГАНІВ МІСЦЕВОГО САМОВРЯДУВАННЯ НА ТЕРИТОРІЇ ГАЛИЧИНИ В ДРУГІЙ ПОЛОВИНІ ХІХ СТОЛІТТЯ
}

У статті здійснено історико-правовий аналіз розмежування компетенції органів місцевого самоврядування в Галичині II пол. XIX ст. З'ясовано, що визначення нових адміністративних одиниць - громад - відбувалося за земельним кадастром 1848 р., який було складено ще напередодні березневої революції. Реорганізація місцевого самоврядування в імперії середини XIX ст. майже не торкнулася правового статусу поміщицьких земель, хіба дещо було обмежено повноваження поміщика. Зроблено висновки, що спочатку селяни не усвідомлювали значущості тих реформ, які відбулися, та доволі зневажливо ставилися до своїх щойно набутих прав, проте з часом ради громадські довели свою дієвість, i на початку XX ст. не в одному селі вже точилася гостра боротьба між різними партіями за мандати депутатів, а особливо - за посаду війта.

Ключові слова: війт, земельний кадастр, гміна, компетенщія, громада, рада, старшина.

Постановка проблеми. В умовах децентралізаційних процесів в Україні актуальною проблемою є визначення, реалізація та розмежування як органів публічної влади, так і їх посадових осіб. Значна увага як науковців, так і практиків публічного управління привернута до вивчення питань розмежування повноважень органів публічної влади, визначення статусних характеристик публічних службовців, їхньої 
сфери діяльності, відповідальності, що є невід'ємними поняттями компетентності. Пошуки оптимальної моделі організації влади на місцях вимагають аналізу власного історичного досвіду та досвіду європейських країн, що робить вивчення досліджуваної теми особливо актуальною.

Формулювання цілей. Метою статті $є$ аналіз процесів формування органів місцевого самоврядування та визначення їх компетенції на території Галичини в другій половині ХІХ століття.

Аналіз останніх досліджень і публікацій. У науковій літературі деякі аспекти компетенції органів місцевого самоврядування на території Галичини в II пол. XIX ст. проаналізовано в наукових працях українських учених-правознавців, зокрема I. Бойко, М. Кащищина, Б. Тищика, М. Никифорака, О. Сухого, І. Настасяк, Н. Панича, Х. МорякПротопопової та ін. Однак питання компетенції органів місцевого самоврядування на території Галичини в II пол. ХІХ ст. залишається й досі недостатньо вивченим.

Виклад основного матеріалу. Оголошення цісарем 22 квітня 1848 р. про відміну панщини 15 травня означало й автоматичне скасування існуючої до того часу на селі так званої патримоніальної системи адміністративного управління. Усі адміністративні функщії: політичні, податкові, поліційні, судові - на низовому рівні перейшли до державних чиновників, а цю наново розбудовану систему адміністративного управління вже можна назвати професійною. Таке кардинальне рушення століттями напрацьованих зв'язків у поміщицьких маєтках сприймалося шляхтою як зазіхання на їхні споконвічні права та руйнування станового принщипу суспільного устрою. Земельна аристократія кілько разів протягом 50-60-х рр. намагалася завадити цим змінам, утім не отримала підтримкиз боку суспільства й була змушена примиритися з новими ліберальними принщипами побудови влади. Епоха станових привілеїв габсбурзької монархії відійшла в минуле, поступившись відкритим політичним змаганням як на загальнодержавному рівні, так і на місцевому.

Визначення нових адміністративних одинищь - громад - відбувалося за земельним кадастром 1848 р., який було складено ще напередодні березневої революції. Кадастральна реформа поклала край адміністративному пануванню дворянства та становості як реального символу суспільної самоідентифікації.

Станом на середину XIX ст. площа поміщицького землеволодіння в Галичині складала 42 \% земель краю [1]. Кількість доміній - панських маєтків (села, що належали одному власнику, який мав права адміністрування на своїй території) - дорівнювала 5523 одиницям водночас, для порівняння, гмін у краї нараховувалося 5948 [2, с. 4]. Тому домінії на рівні з гмінами вважалися первинними осередками територіального управління. Правове положення доміній спочатку визначили розпорядженням намісника краю 10 травня 1857 р., а на законодавчому рівні - у 1866 р. Це відбулося із затвердженням крайового закону про обшари двірські (Gutsgebiete, obszary dworskie) [3], визначивши, що землеволодіння, відомості про які містяться у вотчинній книзі, мають статус самостійної самоуправної одиниці, яка користується правами та несе обов' язки, як і громада. Власне, реорганізація місцевого самоврядування в імперії середини XIX ст. майже не торкнулася правового статусу поміщицьких земель, хіба цим дещо було обмежено повноваження поміщика. I саме завдяки такому статусу доміній польська шляхта, втративши монопольне право на законодавчу діяльність, зберігала свої майнові та соціальні привілеї в краї. 
Домініальне самоврядування було представлене війтом, якого призначав дідич. Обирали його із запропонованих громадою кандидатур, а також із присяжних, що визначалися домініальною громадою, кількість яких не сягала білыше 12, у залежності від чисельності населення. Сам же поміщик, як особа, наділена адміністративною владою над обшаром, підпорядковувся безпосередньо староству. Таке становище проіснувало до 1914 р., коли до крайового закону гмінного були внесені зміни (тим самим долучивши обшари двірські до решти гмін) [4, с. 23].

Спочатку конституювання автономних місцевих громад відбувалося тільки на спадкових землях [5, с. 277]. І лише в 1856 р. сталася зміна громадського устрою в Галичині [6, с. 418, 432]. Одночасно відбувалася й поступова диференщіація компетенщій: так імперський патент від 24 квітня 1859 р. уперше розмежував внутрішні й зовнішні повноваження громад [7, с. 203-222]. Як уже зазначалося, 12 серпня 1866 р. у Відні було затверджене постановлене в березні цього ж року Галищьким сеймом крайове положення для Галичини щодо громад та виборів у громадські представницькі установи [8]. Як же Галицький сейм виписав у своєму законі правове положення місцевих громад? Уже перша стаття констатувала, що місто, містечко або село, що має власний заряд громадський [9], становить громаду. Отже, закон сприймав гміну як давню суспільну інституцію, що здатна до самоорганізації, а відтак і самоуправління. А тому обмеження самоврядних функцій громади держава могла собі дозволити лише задля забезпечення функціонування білыших інституцій. Декларувалася й незалежність місцевого самоврядування від уряду з наданням гміні права самостійно формувати свої органи управління. Водночас, за умов, що в громаді були відсутні призначені державні чиновники, включення органів громадського самоврядування в урядову вертикаль влади відбувалося за допомогою її примусу щодо виконання доручених обов' язків під безпосереднім наглядом з боку старости [10, § 14].

Членами громади закон визнавав тих, хто належав до громади, тобто громадян (нім. Gemeindeangehörige) або співгромадян (нім. Gemeindegenossen). Належність до громади набувалася на підставі закону через уродження в гміні, виходу заміж, надання громадянства або через набуття публічного уряду. Щодо дітей, то в разі їх народження в шлюбі, вони визнавались членами громади, до якої належав батько.

Представнищьким органом громади закон визначав раду громадську (нім. Gemeindeausschuss). Рада складалася з членів двох різновидів: тих, кого обирали, та тих, хто входив до їі складу поза виборами. Кілкість радців залежала від чисельності членів громади, які мали право обирати. Так при наявності 50 активних громадян кількість радиів складала 8 осіб. У громадах обсягом до 200 виборців обирали 12 радщів, до 400 - 18, до 600 - 24, до 1000 - 30, понад 1000 - 36 радців [10, § 19].

Не всі члени, яких об'єднувала громада, мали в ній право голосу. Закон встановлював низку цензів, які були деталізовані в Ординащії виборчій для громад від 12 серпня 1866 р. До кола виборців належали громадяни та співгромадяни, які досягти 24 літнього віку та сплачували гміні податки не менше ніж рік і мали австрійське підданство. Юридичні особи, такі як: держава, край, товариства, спілки, фонди та заклади-могли брати участь у виборах також у разі сплати податку в громаді не менше ніж протягом року [11]. 
Рада обирала війта та асесорів (присяжних) 3-поміж своїх членів, а заступника війта - з ряду присяжних [10, § 23]. Результати виборів заносилися до книги ухвал громади й про них сповіщувалися Староство та Виділ повітовий. I хоча уряд громадський складався не лише з війта, а й з асесорів, на відміну від виділу повітового, він вважався органом не колегіальним, а одноособовим [10, § 28].

Обрана старшина, повинна була скласти перед старостою в присутності делегатів від Виділу повітового та ради громадської так зване «приречення», що було дуже подібне до присяги. Цим приреченням старшина громадська запевняла, що буде вірною та слухняною Цісареві, сумлінно і відповідно до закону, виконувати свої обов' язки в громаді [12, с. 42]. Варто враховувати й те, що громадські обранщі, зазвичай, не отримували платні за свою працю, але в тих випадках, коли рада визнавала це за доцільне, вона могла встановити грошове утримання своїм членам і старшині.

3'ясувавши порядок формування гмінної влади, варто зупинитися на тій компетенщії, якою імперська влада наділила місцеве самоврядування. Себто, громадські справи - це ті, які безпосередньо стосуються громадського життя і які гміна має право вирішувати самостійно, не виходячи за межі, що встановлені відповідними законами. Гміна має право самоврядності, тобто дбає про власний маєток громадський, переймається просвітою, добробутом, спокоєм та безпекою. Ця самоуправність реалізується від імені гміни радою громадською та їі старшиною.

Окрім цих власних справ громади, є й справи публічні, які хоча й покладені на публічну владу, проте через їх безпосередню дотичність до громади, остання повинна долучатися до їх вирішення. Так уряд громадський брав участь у мобілізаційних заходах щодо призову на військову службу (облік, збір та доставка рекрутів), скликання загального ополчення [13]. Наступною публічною справою була справа фіскальна: стягнення податків і зборів вимагало від громади докладання значних організаційних зусиль. Саме тому громади вживали заходи, щоб позбутися цього публічного навантаження. Так перші рішення Трибуналу адміністративного у Відні, які припадають на весну 1883 р., стали на бік громад, підтвердивши, що в обов' язок громади не входить стягнення податків [10, § 2]. Отже, у судовий спосіб громади стали звільнятися від цього публічного тягаря.

Обов'язки, що держава доручала виконувати громаді, складали десятки справ; можна з легкістю прослідити тенденцію спускання донизу обов' язків державної адміністрації. Виконуючи ці доручені справи, гміна діяла як допоміжний орган для Староства [14].

Окреслимо детальніше ті справи, які стосувалися безпосередньо громади і які вирішувалися виключно власним коштом гміни. Її бюджет наповнювався за рахунок додаткового оподаткування членів громади та податків від діяльності окремих підприємств. Перш за все, це вже згадуване право надання приналежності до громади.

Наступне право стосувалося призначення священників та вчителів. Звичайно, воно передбачало утримання священника за кошт громади (далі буде показано, що таке рішення мало важливе значення й для парафії, і для гміни в цілому), як і вчителів, у тих школах, які громада сама заклала та утримувала [10, § 31]. Щодо шкіл, які одержували допомогу від публічних фондів (чи то державних, чи то крайових), то в них громада мала право вирішувати мову викладання в ній [15]. Громада по праву надавала місця в громадських закладах калікам, старцям, одинакам і т. ін. 
Закон громадський дозволяв громаді, а точніше, іï старшині, задпя вирішення громадських справ формувати відповідні служби урядників і слуг, як-от: секретар, писар, лікар, будівничий, поліщіант, нічний сторож тощо. Рада громадська вирішувала, скільки в громадському уряді повинно бути службовців та яку платню їм встановлювати [16].

Також громада мала право видворення за межі їі території таких осіб, як: волоцюг та жебраків; тих, хто, перебуваючи в громаді, не мав жодного заробітку та не міг пояснити мету свого прибування в ній; осіб, випущених із в'язнищі, якщо вони є небезпечними та загрожували чужій власності чи то спокою членів громади.

На громаду покладався обов'язок забезпечувати безпеку своїх членів та їхнього майна. Саме війт повинен був запобігати будь-яким сварам, розбою, крадіжкам тощо. А в разі якщо тяжкі злочини (убивство, підпал, тяжкі тілесні ушкодження, значні крадіжки) траплялися в громаді, то війт мав би всіляко сприяти Судам карним у виявленні злочинщів та притягнення їх до відповідальності. Саме для цих потреб кожна громада утримувала в себе нічну сторожу, а там, де вона була відсутня, коморники повинні були по черзі відбувати сторожу нічну.

Також громада мусила б дбати про розбудову та утримання в порядку громадські дороги, мости, вулищі та площі. Такий обов'язок на гміни було покладено законом дороговим від 7 липня 1885 р. [17].

3 метою охорони польової власності (усе, що знаходилося на полі, а то всі предмети, які отримані з рільного господарства і мали до нього будь-яке відношення в найширшому розумінні, є польною власністю) кожна гміна повинна утримувати стражників польних, яких затверджувала на посаді та заприсягала Староству [17]. Щодо покарання злочинщів польних, які вчинили проступок на грунтах громадських, то його здійснював війт разом із двома присяжними (асесорами).

Однією з важливих справ, що покладалась на громаду, був догляд за торговельною діяльністю, яка чинилась на території громади, над мірами та вагами, що використовувалися при цій торгівлі. Саме старшина здійснювала догляд за різниками, пекарями, будь-якими купщями, щоб вони продавали здоровий та якісний товар, застосовуючи при цьому справедливі ваги та міри. Також громада мала право стягувати торговий збір від кожного, хто в цей день збував свій товар на громадському торзі [18]. Власне, торговий порядок та тарифи торгівельного збору через Староство подавалися на затвердження до Наміснищтва [19].

Окрім того, громада повинна була опікуватися всім тим, що могло зашкодити здоров' ю мешканщів громади. Насамперед доглядати за чистотою постоялих дворів, за дорогами, площами, хатами, каналами, кринищями, річками та ставками. На кожного члена громади покладався обов'язок дбати про чистоту власної хати та прилеглої території. Рада громадська повинна була або утримували лікаря або забезпечити його безпосередню доступність для членів громади, а вчена акушерка мала б бути в гміні обов' язково - задля допомоги людям при слабкості. У разі виникнення підозри щодо епідемічного захворювання, війт мусив би невідкладно сповістити про це Староство та очікувати повітового лікаря. Також розпорядженням Намісника від 11 квітня 1876 р. у громадах запроваджувалося обов'язкове щеплення дітей від віспи [20].

Так само уважно гміна повинна була ставитися до здоров'я тварин та боронити ïx від зарази. Так заборонялось допускати на територію гміни тварину без паспорта, 
який видавався старшиною громадською. Той, хто виявляв хворобу у тварини, повинен був негайно звідомити про це уряд громадський та забезпечити ізоляцію хворої тварині. Своєю чергою війт мав інформувати Староство, що висилало ветеринара, який вживав би необхідні заходи, аж до забою тварини [10, § 62]. Вартість забитої тварини відшкодовувалася власнику за рішенням Наміснищтва. Ті, хто приховував факт хвороби або зволікав звідомлювати громадську владу, притягувався до відповідальності або у вигляді двох місяців арешту, або штрафом у розмірі 3000 злотих рейнських (гульденів).

Старшина громадська була зобов'язана опікуватися та доглядати за челяддю, слугами та заробітчанами. Суть цієї опіки полягала в запобіганні утискам з боку господарів, які не повинні були переобтяжувати слуг. Одночасно старшина мала право й покарання тих, хто ухилявся від виконання покладених на них обов'язків.

На громаду також покладався обов'язок дотримання публічних звичаїв. Шанобливе ставлення до неділь і свят, у які не можна проводити торги та ярмарки. Музика та танщі під час свят можливі лише з дозволу уряду громадського, та й то лише після вечірнього богослужіння. На забавах мав би панувати спокій та порядок. Також старшина громадська повинна запобігати п'янству. Не допускати напризволяще множення шинків по селах та дбати, щоб о 22-й вони всі були вже зачинені $[10, \S 35,56]$. Утім, вважалось, що кращим запобіжником п'янства є запровадження в громаді братерств тверезості та товариств просвіти.

Опіка над убогими також покладалась на гміну, для чого запроваджувався відповідний фонд, до якого спрямовувались стягнення, що накладалися старшиною громадською та судом карним на порушників [21]. Сюди ж спрямовувалися й збори за дозвіл на музику й танщі та ті квоти, які своїм рішенням визначала Рада громадська. Безпосередньо справами вбогих переймався війт [22, с. 91]. Так само громада запроваджувала добродійні заклади: штиталі, бурси для бідної молоді, доми сиріт, калік тощо.

Доглядала старшина громадська й за будівництвом на ії території, погоджуючи із забудовниками плани майбутніх будівель щодо їх відповідності існуючим нормам та узгодженості із сусідами, а також дотримання пожежних норм безпеки, перевіряючи пожежний стан щонайменше три рази на рік.

Важливою громадською справою було утримання школи, бо саме на неї покладалося релігійно-моральне виховання дітей, яких треба було довести до такого стану, щоб вони виросли добрими та заможними людьми як для себе, так і для інших. Школа повинна була надати дітям відповідних знань і навичок, розвивати їхні здібності, а також формувати підвалини для виховання з них достойних громадян і членів суспільства. Це означало, що школа з виховного закладу перетворювалася на загальноосвітній [23]. Яка школа - такими будуть й люди в громаді [23]. Громада 3обов'язана заснувати народну школу та утримувати народного вчителя. На все це спрямовувалось 9 \% всіх податків громадських разом із податками державними, що сплачувались у громаді. Щодо обшар двірських, то в них на утримання школи витрачали до $3 \%$ [24].

Проте обов' язок покладався не лише на громаду, а й на ії членів. Батьки мусили посилати своїх дітей до школи відтоді, як їм сповнилося шість років, і доти, доки не виповниться дванадцять. А вже після дванадцяти - ще два роки додаткового нав- 
чання кожної неділі. Відповідальне ставлення до освітньої справи ілюструвало положення того, що вчитель був зобов' язаний раз на місяць звідомлювати Раду шкільну місцеву щодо дітей, які не відвідують школу, а рада своєю чергою мала право притягнути батьків до відповідальності, присуджуючи їм або грошовий штраф у розмірі до 50 австр. злотих або арешт до 14 діб у разі ухиляння від обов'язків. Виконання покарання покладалося на старшину громадську [25].

Також гміна повинна була долучатися до вирішення спорів, що виникали посеред членів громади. Звичайно, основний тягар покладався на судову владу, утімсторони могли добровільно зголоситися на розгляд справи судом громадським - «урядом розємним громадським» [25]. Крайові особливості уряду розємного громадського встановлювались галищьким крайовим законом [25]. У параграфі 1 цього закону йшлося, що «уряд розємний для поєднаня, залагоди сторін спірних має бути установлений в кождій громаді». Таким чином, рада громадська зобов' язана обрати з громадищонайменше трьохповажних людей, відомих своєю сумлінністю та правістю, та доручити їм вирішити справу по суті. Головувати в такому суді повинен очільник громади. Він сповіщав Виділ повітовий та Староство про вибір суду громадського, який уповноважений розглядати справи в такому складі протягом трьох років. Також обраний склад суду повинен скласти присягу в Старостві, пообіцявши чинити суд чесно, ставитись однаково як до бідних, так і до багатих та не брати подарунків. До суду призначався писар, який теж складав присягу в Старостві. У гмінах, що об'єднують понад 4000 мешканщів, сума позову не могла бути більшою аніж 300 австр. злотих. Там же, де кількість мешканщів менша, то й справи розглядалися такі, що не перевищували суми позову в 100 австр. злотих [10, §32, §60].

Головною метою суду було замирення сторін та приведення їх до угоди, яка відповідним чином реєструвалася в журналі. Угода, що укладалася перед судом громадським, мала юридичну силу вироку суду та в разі відмови від ії добровільного виконання могла бути представлена до суду з метою їі примусового виконання [10, §59].

Закон громадський закріплював за старшиною громадською право притягати до відповідальності за правопорушення в справах громадських, бо невиконання постанов та ухвал ради громадської повинно тягнути за собою певну відповідальність. Притягання до відповідальності покладалося на війта та двох асесорів (присяжних), які виносили рішення білышістю голосів. Щодо санкцій за ті чи інші порушення, то окремі 3 них, як було показано вище, передбачалися самим закономгромадським, а решта встановлювалася спеціальними законами, як цісарськими, так і крайовими. Але закон громадський містив і таку норму, що в разі відсутності в чинних законах санкції за те чи інше правопорушення, старшина громадська могла застосувати до винного грошовий штраф, який не міг перевищувати 15 австр. злотих, а в разі неможливості його сплатити - заарештувати порушника на строк до 5 діб [26]. До компетенщії ради громадської закон відносив право встановити конкретну санкцію, але в межах, які було визначено законом. В особливих, екстраординарних випадках закон надавав право війтові накласти штраф на порушника в розмірі до 3 австр. злотих або арешт на добу [10, § 28].

Щодо питань побудови церков та парафіяльних будинків на території гміни, а також їх подальшого утримання, то формально ці питання не належали до компетенщії громадської, утім вони стосувалися самих парафіян. А тому для вирішення цих питань церковна громада (парафія) мала створити комітет церковний із п'яти членів. 
Саме на нього покладався тягар організації будови та подалышого утримання церков і молитовних будинків.

Отже, попередній огляд свідчить, що сфера управлінських функцій гміни, як власних, так і делегованих, була достатньо детально регламентована в чинному законодавстві, як загальними, так і спеціальними законами, а ії дотримання забезпечувалося багаторівневим контролем органів державної влада. І метою цього контролю, як зазначала влада, було боронити інтереси членів громади від розпоряджень та заходів, які могли б порушити ці інтереси [10, § 30].

Також детальної регламентації в законодавстві зазнало й розподілення цих функцій поміж органами влади громади.

Власне, як вже було зазначено, рада громадська обіймала найвищу владу в громаді. Вона в межах своєї компетенції постановляла рішення у важливих справах громадських та контролювала їх виконання. І старшина громадська, і війт були підконтрольні раді та мусили виконувати ії постанови [10, § 40]. До компетенщії ради закон відносив рішення, що стосувалися справ маєткових, а саме: розпорядження маєтком та добром громадським; визначення способів використання маєтку та добра; ухвалення річного бюджету та контроль за його дотриманням; визначення та погодження річних рахунків громадських; надання згоди на початок проваджень щодо вирішення спорів або припинення їх. Також закон призначав заступників правних та затверджував угоди, яких сторони досягли в процесі; і взагалі вирішував усі справи, які хоч і не належали до управління громадським маєтком, але визнавав за доцільне їх вирішити [10, § 38].

Наступне коло питань, що покладалися на раду громадську, це: обрання Старшини громадської; розв'язання всіх питань щодо надання права приналежності до громади; виконання патронажних функцій від імені громади та вирішення фундаційних питань; ухвалення умов взаємовідносин у справах з іншими громадами або представниками двірських обшар; обрання мужів довіри до суду громадського [10, §37].

І останнє коло питань, що вирішувала рада, стосувалося їі контрольних функцій: нагляду за діяльністю Старшини громадської; проведення ревізії каси громадської двічі на рік [10, § 45]; розгляд скарги на розпорядження та постанови громадського уряду щодо власних громадських справ [10, §46].

Робота ради громадської відбувалась у формі публічних засідань, які проходили під головуванням війта або його заступника. Саме війт організовував проведення засідання, слідкував за порядком та веденням протоколу [10, § 47]. Задля постановлення рішення треба було, щоб за нього віддала свої голоси білышість присутніх на засіданні. Щодо уряду громадського чи то старшини, то їй належала виконавча влада, і вона була зобов' язана виконувати все, що постановить рада, або те, що вона сама вважає за доцільним у межах своєї компетенщіі. Отже, Старшині заборонялося виходити за межі повноважень, установлених у законі громадському, та зазіхати на компетенцію ради громадської. У разі виникнення непорозуміння з радою, коли старшина переконана, що рішення ради є незаконним, то така суперечність вирішувалася через Староство або Виділ повітовий [10, § 48].

Щодо очільника громади, війта, то він визнавався тим, хто стоїть на сторожі добра та порядку в гміні. На нього покладалося ведення всіх справ старшини громадської, виконання ухвал ради громадської та розпоряджень, що надходили від державної влади. 
Допомагали війтові в його справах двоє присяжних (асесори), яким він міг доручити (під свою відповідальність) виконання конкретного доручення [10, §51].

Саме війт повинен був дбати про маєток громадський, доглядати, як використовується громадське майно, опікуватись спокоєм та безпекою в гміні. Вирішення питань, що знаходяться в компетенщії ради громадської, він здійснював виключно відповідно до постановлених рішень. Лише в невідкладних справах війт міг прийняти рішення самостійно, але 3 подалышим його затвердженням на найближчому засіданні ради [10, § 58]. Свої обов' язки очільник громади здійснював за допомогою урядників, поліщіантів та слуг громадських. У разі коли їх спільних зусиль не вистачало для виконання рішення, війт міг звернутися до Староства за допомогою, яке й повинно надати йому в поміч жандармів, котрі мають виконувати його розпорядження $[10, \S 52]$.

I нарешті, саме війт представляв громаду в стосунках зовні, перед владою та іншими суб'єктами правовідносин. Усе листування від імені громади відбувалося за підписом війта або уповноваженого на те його заступника та одного з асесорів, як й укладання будь-яких правочинів, у якому однією зі сторін виступала гміна. Ті ж питання, які потребували рішення ради громадської при їх юридичному оформленні потребували обов' язкового посилання в тексті на ухвалу ради, а сам документ мав би бути підписаний двома радниками громадськими. Також обов' язковим атрибутом документа, що виходив від імені громади, був відбиток громадської печатки [10, § 54].

За виконання покладених на нього обов'язків війт відповідав перед громадою (щодо власних справ) та перед урядом (щодо справ їм доручених). Поряд із війтом відповідальність покладалась і на членів старшини, якщо з їхньої вини або через недбалість громаді була завдана шкода. Рада громадська мала право вимагати відшкодування заподіяної шкоди, а в разі відмови від добровільного відшкодування збитків, вона звідомлювала Староство і Виділ повітовий та, за умови отримання їхньої згоди, могла звертатися з позовом до суду. Причому Староство мало своєю владою відсторонити звинуваченого від урядування до завершення розгляду справи [10, § 64].

Висновки. Отже, попри подвійний контроль із боку державної влади, гміна в багатьох питаннях відчувала себе автономною, і в цих умовах функціонування органів місцевої громадської влади західноукраїнське суспільство почало проходити школу самоврядування. Ті демократичні ідеали, які завжди супроводжували існування громад, стали джерелом нових політичних течій, а для українщів - ще й інструментом захисту нащіональних прав. Після набуття чинності Закону громадського 1866 р., коли його положення запращювали в краї, кожна гміна стала обирати власну раду та свого очільника. Спочатку селяни не усвідомлювали значущості тих реформ, які відбулись, і доволі зневажливо ставилися до своїх щойно набутих прав, проте з часом ради громадські довели свою дієвість та на початку XX ст. не в одному селі вже точилася гостра боротьба між різними партіями за мандати депутатів, а особливо - за посаду війта [27].

\section{Використані джерела:}

1. Областное, административное и общинное устройство Галищіи по австрійскому законодательству. Петроградъ: Государственная типографія, 1915. XXXIII, 185 c. С. XV.

2. Głąbiński S. Stosunki społeczne i ekonomiczne w Galicyi. Lwów: Druk W. L. Anczyca i Społki, 1908. $41 \mathrm{~s}$. 
3. Законь зъ дня 12 Серпня 1866 р. про обшаридвірські. Вбстникъ законовъ и роспоряжєнӥй краєвыхъ для Королевства Галииіи и Володимиріии разомъ съ великимъ Княжествомъ Краковскимъ. Рокъ 1866. № 20. Львовъ: Въ ц. к. Галищййской скарбово-державной типографїи, 1866.

4. Kumaniecki K. W. Ustrój władz samorządowych na ziemiach Polski w zarysie. Warszawa; Kraków: J. Czerniecki, 1921. 80 s.

5. Die Habsburgermonarchie 1848-1818. Band II. Verwaltung und Rechtswesen / by Peter Wandruszka, Adam \& Urbanitsch. Wien: Verlag der Österreichischen Akademie der Wissenschaften, 1975. XVIII+791 s.

6. Mayrhofer E. Handbuch für den politischen Verwaltungsdienst in den im Reichsrate vertretenen Königreichen und Ländern mit besonderer Berücksichtigung der diesen Ländern gemeinsamen Gesetze und Verordnungen. Wien: Verlag Manz, 1875. Vol. II. 1624 s.

7. Kaiserliches Patent vom 24 April 1859, wirtfam für den ganzen Umfang des Reiches, mit Ausnahme des lombardifch venetianifchen Königreiches, Dalmatiens und des Militär-Bränzlandes womit ein neues Semeindegefeb er Laffen wird. Reichs-Gesetz-Blatt für das Kaiserthum Deterreich RGBI. Jahrgang 1859. № 58. Wien: Aus der faizerlich-föniglichen Boz und Staatsbrucferei, $1859.826 \mathrm{~s}$.

8. Die Habsburgermonarchie 1848-1818. Band II. Verwaltung und Rechtswesen / by Peter Wandruszka, Adam \& Urbanitsch. Wien: Verlag der Österreichischen Akademie der Wissenschaften, 1975. XVIII+791 s. S. 280; Ustawa gminna dla Krolestva Galicyi i Lodomeryi z Wielkiem Ksiestwem Krakowskiem z dnia 12. Sierpnia 1866 r. D.U.Kr. Lwow. Rok 1866. Cz. XI. № 19. S. 62; Законъ громадскій обовязуючій въ Королевствъ Галичины и Володимиріъ зъ великимъ Князъвствомъ Краковскимъ, зъ дня 12 Серпня 1866 р. Въстникъ законовъ и роспоряжєний краєвыхъ для Королевства Галииїи и Володимирїи разомъ съ великимъ Княжествомъ Краковскимъ. Рокъ 1866. № 19. Львовъ: Въц. к. Галищййской скарбово-державной типографїи, 1866.

9. Broński K. Rola samorządu w rozwoju prowincjonalnych miast galicyjskich w dobie autonomicznej. Zeszyty Naukowe Uniwersytetu Ekonomicznego w Krakowie, 2000. № 548. S. 62-63.

10. Ustawa gminna dla Krolestva Galicyi i Lodomeryi z Wielkiem Ksiestwem Krakowskiem z dnia 12. Sierpnia 1866 r. D.U.Kr. Lwow. Rok 1866. Cz. XI. № 19, § 2, §14, §19, § $23, \S 28-32, \S 35, \S 37, \S 38, \S 40, \S 46-48, \S 51, \S 52, \S 54, \S 56, \S 58, \S 60, \S 62, \S 64$.

11. Kumaniecki K. W. Ustrój władz samorządowych na ziemiach Polski w zarysie. Warszawa; Kraków: J. Czerniecki, 1921. S. 80.

12. Рішення Трибуналу адміністративного у м. Відні № 577 від 14.03 .1883 р., № 501 від 11.04.1883 р. Левицький К. А. Наш закон громадський або які ми маєм права і повинності в громаді. ПросВіта. Львів: Т-во «Просвіта». 1889. С. 1-122.

13. Ustawa z dnia 13 Marca 1889, zaprowadzająca ustawę gminną dla miast: Biała, Bochnia, Brody, Brzeźany, Buczacz, Drohobycz, Gorlice, Gródek pod Lwówem, Jarosław, Kołomyja, Krosno, Nowy Sącz, Podgórze, Przemyśl, Rzeszów, Sambor, Sanok, Śniatyn, Sokal, Stanisławów, Stryj, Tarnopol, Tarnów, Trembowla, Wadowice, Wieliczka, Złoczów, Źółkiew. D.U.Kr. Rock 1889. Wydany i rozesłany dnia 10 Kwietnia 1889. Częśź VII. Lwów: Z drukarni Wł. Łozińskiego, 1889.S. 89.

14. Краєвый законъ зъ 22 червня 1867. Ч. 13 В. з. кр. О язьщъ выкладовомъ въ школахъ народныхъ (людовыхъ) КоролЂвствъ Галичины и Володимиріи зъ королЂвствомъ Краковскимъ. Праљда. 1876. Арт. ІІ. Ч. 123. С. 1-2.

15. Законъ дороговий въ Королевствъ Галичины и Володимиріъ зъ великимъ Князъвствомъ Краковскимъ, зъ дня 7 липня 1885 р. Въстникъ законовъ и роспоряжєній краєвыхъдяя Королевства Галииіи и Володимиріи разомъ съ великимъ Княжествомъ Краковскимъ. Рокъ 1885. № 39. Львовъ: Въ ц. к. Галицййской скарбово-державной типографїи, 1885. 
16. Законь про охорону полів въ Королевствъ Галичины и Володимиріъ зъ великимъ Князъвствомъ Краковскимъ, зъ дня 17 липня 1876 р. Въстникъ законовъ и роспоряжєній краєвьхъ для Королевства Галиий и Володимирӥи разомъ съ великимъ Княжествомъ Краковскимъ. Рокъ 1876. № 29, § 24, 28. Львовъ: Въ ц. к. Галищййской скарбово-державной типографӥи, 1876.

17. Законъ промисловий, зъ дня 15 березня 1883 р. Въстникъ законовъ державныхъ для королевствъ и краевъ въ державной думъ заступленыхъ. Рокъ 1883. № 39, § 69, § 70. Въдень: Тискомъ цъсарско-королевской надворнои и статскои печатнъ, 1883.

18. Розпорядження Намісництва зъ 11 цветня 1876 р. Вістник законів і розпоряджень краєвих для Королївств Галичини і Володимириї враз з Великим Князівством Краківським. Рокъ 1876. №. 16.727. Львовъ: Въ ц. к. Галищййской скарбово-державной типографїи, 1876.

19. Законъ санітарний, зъ дня 29 лютого 1880 р. Въстникъ законовъ державныхъ для королевствъ и краевъ въ державной думъ заступленыхъ. Рокъ 1880. № 35. Въдень: Тискомъ цъсарскокоролевской надворнои и статскои печатнъ, 1880.

20. Розпорядження Намісництва зъ дня 14 червня 1856 р. Вістник законіВ і розпорядженъ краєвих для Королївств Галичини і Володимириївраз з Великим Князівством Краківським. Рокъ 1856. №. 20. Львовъ: Въ ц. к. Галищййской скарбово-державной типографїи, 1856.

21. Гр. Про школьництво народне в Австріи. Учитель. 1891. Р. 3. Ч. 24. С. 371.

22. Левищький К. А. Наш закон громадський або які ми маєм права і повинності в громаді. Просвіта. Львів: Т-во «Просвіта». 1889. С. 1-122.

23. Ustawa z dnia 2 maja 1873 o zakładaniu i utrzymywaniu publicznych szkół ludowych, i obowiązku posyłania do nich dzieci. Ustawy i najważniejsze Rozporzadzenia dla szkót ludowych w królestwie Galicyi i Lodomeryi wraz z Wielkiem Księstwem Krakowskiem. Lwów, 1879. S. 1-21. Apт. 18., 43-44.

24. Законъ державный, зъ дня 21 вересня 1869 р. Въстникъ законовъ державныхъ для королевствъ и краевъ въ державной думъ заступленыхъ. Рокъ 1869. № 150. Въдень: Тискомъ цъсарско-королевской надворнои и статскои печатнь, 1869.

25. Законь про уряд розємний громадський, зъ дня 6 березня 1875 р. Вістник законіВ $i$ розпоряджень краєвих для Королїств Галичини і Володимириї враз з Великим Князівством Краківським. Рокъ 1875. №. 27, § 27, § 29-31. Львовъ: Въ ц. к. Галищййской скарбово-державной типографїи, 1875.

26. Rauscher. Die Gemeindeverewaltung u. Gemeindeverefassung. Friedmann E. Das Österreichische Recht / Arthur Sandig und Josef Wach. 3 Bände. Wien: Deutsches Verlagshaus Bong \& Co., 1905. X, 1488, 39S. Bd. I.S. 953.

27. Гулюк Ю. Жаб'є: Іісторичні розповіді від часу залюднення цього краю до 1939 року. Верховина: Гуцульщина, 2004. 176 с.

\section{References:}

1. Oblastnoe, admynystratyvnoe y obshchynnoe ustroistvo Halytsiy po avstriiskomu zakonodatelstvu. (1915) Petrohradъ: Hosudarstvennaia typohrafiia. XXXIII, XV. [in Russian].

2. Głąbiński, S. (1908) Stosunki społeczne i ekonomiczne w Galicyi. Lwów: Druk W. L. Anczyca i Społki. [in Polish].

3. Zakon zъ dnia 12 Serpnia 1866 r. pro obshary dvirski. Vøstnykъ zakonovø y rosporiazhienii kraievukhъ dlia Korolevstva Halytsiy y Volodymyriy razomъ sъ velykymъ Kniazhestvomъ Krakovskymъ Vestnik laws and regulations for the Kingdom of Galicia and Volodymyr at the same time with the Grand Duchy of Krakow, 20. Lvovъ: Vъ ts. k. Halytsiiskoi skarbovo-derzhavnoi typohrafiy. [in Polish].

4. Kumaniecki, K. W. (1921) Ustrój władz samorządowych na ziemiach Polski w zarysie. Warszawa; Kraków: J. Czerniecki. [in Polish]. 
5. Die Habsburgermonarchie 1848-1818. (1975) Band II. Verwaltung und Rechtswesen. Peter Wandruszka, Adam, \& Urbanitsch. Wien: Verlag der Österreichischen Akademie der Wissenschaften, XVIII+. [in German].

6. Mayrhofer, E. (1875) Handbuch für den politischen Verwaltungsdienst in den im Reichsrate vertretenen Königreichen und Ländern mit besonderer Berücksichtigung der diesen Ländern gemeinsamen Gesetze und Verordnungen. Wien: Verlag Manz, vol. II. [in German].

7. Kaiserliches Patent vom 24 April 1859, wirtfam für den ganzen Umfang des Reiches, mit Ausnahme des lombardifch venetianifchen Königreiches, Dalmatiens und des MilitärBränzlandes womit ein neues Semeindegefeb er Laffen wird. (1859) Reichs-Gesetz-Blatt für das Kaiserthum Deterreich RGBI. Jahrgang, 58. Wien: Aus der faizerlich-föniglichen Boz und Staatsbrucferei. [in German].

8. Die Habsburgermonarchie 1848-1818. Band II. Verwaltung und Rechtswesen. Peter Wandruszka, Adam, \& Urbanitsch. (1975) Wien: Verlag der Österreichischen Akademie der Wissenschaften, XVIII, 280; (1866) Ustawa gminna dla Krolestva Galicyi i Lodomeryi z Wielkiem Ksiestwem Krakowskiem z dnia 12. Sierpnia 1866 r. D.U.Kr. Lwow. Rok. Part. XI, 19, 62; (1866) Zakonъ hromadskii oboviazuiuchii vъ Korolevstvъ Halychyni y Volodymyriъ zъ velykymъ Kniazъvstvomъ Krakovskymъ, zъ dnia 12 Serpnia 1866r. Vъstnykъ zakonovъ y rosporiazhienii kraievblkhъ dlia Korolevstva Halytsiy y Volodymyriy razomъ sъ velykymъ Kniazhestvomъ Krakovskymъ- Vestnik laws and regulations for the Kingdom of Galicia and Volodymyr at the same time with the Grand Duchy of Krakow, 19. Lvovъ: Vъ ts. k. Halytsiiskoi skarbovo-derzhavnoi typohrafiy. [in German-Polish-Russian].

9. Broński, K. (2000) Rola samorządu w rozwoju prowincjonalnych miast galicyjskich w dobie autonomicznej. Zeszyty Naukowe Uniwersytetu Ekonomicznego w Krakowie - Scientific Journals of the University of Economics in Krakow, 548, 62-63. [in Polish].

10. Ustawa gminna dla Krolestva Galicyi i Lodomeryi z Wielkiem Ksiestwem Krakowskiem z dnia 12. Sierpnia 1866 r. D.U.Kr. (1866) Lwow, part XI, 19, § 2, §14, § 19, § 23, § $28-$ $32, \S 35, \S 37, \S 38, \S 40, \S 46-48, \S 51, \S 52, \S 54, \S 56, \S 58, \S 60, \S 62, \S 64$. [in Polish].

11. Kumaniecki, K. W. (1921) Ustrój władz samorządowych na ziemiach Polski w zarysie. Warszawa; Kraków: J. Czerniecki, 80. [in Polish].

12. Rishennia Trybunalu administratyvnoho u m. Vidni № 577 vid 14.03 .1883 r., № 501 vid 11.04.1883 r. Levytskyi, K. A. (1889) Nash zakon hromadskyi abo yaki my maiem prava i porynnosti v hromadi. Prosvita. Lviv: T-vo «Prosvita», 1-122. [in Ukrainian].

13. Ustawa z dnia 13 Marca 1889, zaprowadzająca ustawę gminną dla miast: Biała, Bochnia, Brody, Brzeźany, Buczacz, Drohobycz, Gorlice, Gródek pod Lwówem, Jarosław, Kołomyja, Krosno, Nowy Sącz, Podgórze, Przemyśl, Rzeszów, Sambor, Sanok, Śniatyn, Sokal, Stanisławów, Stryj, Tarnopol, Tarnów, Trembowla, Wadowice, Wieliczka, Złoczów, Źółkiew. D.U.Kr. (1889). Wydany i rozesłany dnia 10 Kwietnia 1889. Part VII. Lwów: Z drukarni Wł. Łozińskiego, 89. [in Hungarian].

14. Kraievyi zakonъ zъ 22 chervnia 1867, part 13. (1867) V.z. kr. O yazыts' vыkladovomъ vъ shkolakhъ narodnыkhъ (liudovykhъ) KorolЂvstvъ Halychynы y Volodymyriy zъ korolЂvstvomъ Krakovskymъ. Pravda - Truthю Art. II, part 123, 1-2. [in Russian].

15. Zakon" dorogovij v" Korolevstv" Galichiny i Volodimiri" z" velikim" Knyaz"vstvom" Krakovskim", z" dnya 7 lipnya 1885 r. (1885) V"stnik" zakonov" i rosporyazhenï kraevyh" dlya Korolevstva Galicii i Volodimirii razom" s" velikim" Knyazhestvom" Krakovskim" - Bulletin of laws and regulations for the Kingdom of Galicia and Volodymyr at the same time with the Grand Duchy of Krakow, 39. Lvovъ: Vъ ts. k. Halytsiiskoi skarbovo-derzhavnoi typohrafiy. [in Russian].

16. Zakon" pro ohoronu poliv v" Korolevstv" Galichiny i Volodimiri" z" velikim" Knyaz"vstvom" Krakovskim", z" dnya 17 lipnya 1876 r. V"stnik" zakonov" i rosporyazhenï kraevyh" dlya Korolevstva Galicïi Volodimirii razom" s" velikim" Knyazhestvom" Krakovskim". V"stnik" zakonov 
"i rosporyazhenï kraevyh" dlya Korolevstva Galicii i Volodimirï razom "s" velikim "Knyazhestvom" Krakorskim" - Bulletin of laws and regulations for the Kingdom of Galicia and Volodymyr at the same time with the Grand Duchy of Krakow, 29, § 24, § 28. Lvovъ: Vъ ts. k. Halytsiiskoi skarbovo-derzhavnoi typohrafiy. [in Russian].

17. Zakon" promislovij, z" dnya 15 bereznya 1883 r. (1883) V"stnik" zakonov" derzhavnyh" dlya korolevstv" i kraev" v" derzhavnoj dum" zastuplenyh" Zakonъ promyslovyi, zъ dnia 15 bereznia $1883 \mathrm{r}$. - Vestnik laws of sovereign for kingdoms and territories in the sovereign duma of intercessors, $39, \S 69, \S 70$. Viden: Tyskomъ tsъsarsko-korolevskoi nadvornoy y statskoy pechatnъ.

18. Rozporyadzhennya Namisnictva z" 11 cvetnya 1876 r. Vistnyk zakoniv i rozporiadzhen kraieoykh dlia Korolivsto Halychyny i Volodymyryi vraz z Velykym Kniazivstoom Krakivskym - The Bulletin of Laws and Regulations of the Territories for the Kingdoms of Galicia and Volodymyr at the same time with the Grand Duchy of Krakiv, 16.727. Lvovъ: Vъ ts. k. Halytsiiskoi skarbovo-derzhavnoi typohrafiy. [in Russian].

19. Zakon" sanitarnij, z" dnya 29 lyutogo 1880 r. (1880) V"stnik" zakonov" derzhavnyh" dlya korolevstv" i kraev" $v$ " derzhavnoj dum" zastuplenyh" - Vestnik laws of sovereign for kingdoms and territories in the sovereign duma of intercessors. V"den': Tiskom" c"sarsko-korolevskoj nadvornoi i statskoi pechatn", 35. [in Russian].

20. Rozporiadzhennia Namisnytstva zъ dnia 14 chervnia 1856 r. (1856) Vistnyk zakoniv $i$ rozporiadzhen kraievykh dlia Korolivsto Halychyny $i$ Volodymyryi vraz z Velykym Kniazivstvom Krakivskym - Bulletin of laws and regulations of the regional for the Kingdoms of Galicia and Vladimir together with the Grand Duchy of Krakow, 20. Lvovъ: Vъ ts. k. Halytsiiskoi skarbovo-derzhavnoi typohrafiy. [in Ukrainian].

21.Hr. Pro shkolnytstvo narodne v Avstriy.(1891) Uchytel- Teacher, section 3, part. 24, 371.

22. Levytskyi, K. A. (1889) Nash zakon hromadskyi abo yaki my maiem prava i povynnosti v hromadi. Prosvita. Lviv: T-vo «Prosvita», 1-122. [in Ukrainian].

23. Ustawa z dnia 2 maja 1873 o zakładaniu i utrzymywaniu publicznych szkół ludowych, i obowiązku posyłania do nich dzieci. (1879) Ustawy i najważniejsze Rozporządzenia dla szkót ludowych w królestwie Galicyi i Lodomeryi wraz z Wielkiem Księstwem Krakowskiem - The measures taken to comply with the provisions of the Treaty establishing the European Community shall apply to the Galician and Lodomers of Poland. Lwów. Art. 18. Art. 43-44, 1-21. [in Polish].

24. Zakon" derzhavnyi, z" dnia 21 veresnia 1869 r. (1869) V"stnyk" zakonov" derzhavnykh" dlia korolevstv" y kraev" $v^{\prime \prime}$ derzhavnoi dum" zastuplenykh"-Vestnik laws of the sovereign for the kingdoms and territories in the sovereign thought of the intercessors, 150. Viden: Tyskom" ts"sarskokorolevskoi nadvornoy y statskoy pechatn". [in Russian].

25. Zakon" pro uriad roziemnyi hromadskyi, z" dnia 6 bereznia 1875 r. Vistnyk zakoniv i rozporiadzhen kraievykh dlia Korolivsto Halychyny $i$ Volodymyryi vraz z Velykym Kniazivstvom Krakivskym - Bulletin of laws and regulations of the regional for the Kingdoms of Galicia and Vladimir together with the Grand Duchy of Krakow, 27, § 27, § 29-31. Lvov": V" ts. k. Halytsiiskoi skarbovoderzhavnoi typohrafiy, 1875. [in Ukrainian].

26. Rauscher. Die Gemeindeverewaltung u. Gemeindeverefassung. (1905) Friedmann E. Das Österreichische Recht. Arthur Sandig, \& Josef Wach. 3 Bände. Wien: Deutsches Verlagshaus Bong,\& Co., X, 1488, I, 953.

27. Huliuk, Yu. (2004) Zhab'ie: Iistorychni rozpovidi vid chasu zaliudnennia tsoho kraiu do 1939 roku. Verkhovyna: Hutsulshchyna. [in Ukrainian]. 


\section{Бутырин Е. А., кандидат юридических наук, доцент кафедры теории и философии права Одесского государственного университета внутренних дел (г. Одесса, Украина)}

\section{КОМПЕТЕНЦИЯ ОРГАНОВ МЕСТНОГО САМОУПРАВЛЕНИЯ НА ТЕРРИТОРИИ ГАЛИЧИНЫ ВО ВТОРОЙ ПОЛОВИНЕ ХІХ ВЕКА}

В статье осуществлен историко-правовой анализ разграничения компетенщии органов местного самоуправления на территории Галичины во второй половине XIX века. Выяснено, что определение новых административньх единищ- общин-происходило на основании земельного кадастра 1848, который было составлен еще накануне февральской революции в Австрии. Реорганизация местного самоуправления в империи в середине XIX в. почти не затронула правового статуса помещичьих земель, однако реформа незначительно ограничила полномочия помещиков. Сделаны выводы, что в начале крестьяне не понимализначимости тех реформ, которые состоялись, и поэтому довольно принебрежительно относились к своим, только приобретенным правам, однако со временем совет общины доказал свою эффективность, потому в начале XX ст. во многих селах уже шла острая борьба между различными партиями за мандаты депутатов, а особенно - за должность войта.

Ключевые слова: войт, земельный кадастр, гмина, компетенщия, община, совет, старшина.

Butyrin E.,

Candidate of Law, Associate Professor of the Theory of Philosophy of Law

Odesa State University of Internal Affairs

(Odesa, Ukraine)

\section{COMPETENCE OF LOCAL GOVERNMENT BODIES ON THE TERRITORY OF GALICIA IN THE SECOND HALF OF THE XIX CENTURY}

The article provides a historical and legal analysis of the delimitation of local governments' competence in Halychyna in the second part of the XIX century. It has been determined that the definition of new administrative units - communities - was based on the land cadastre of 1848, which was compiled on the eve of the March Revolution. Reorganization of local self-government in the empire in the middle of the XIX century almost did not affect the legal status of landed estates, except to some extent, limited the powers of the landlord. The law defined the community council as the representative body of the community. The Council consisted of two members, those who were elected and those who were members beyond the elections. The number of councilors depended on the number of community members who had the right to elect. The public Council's work took place in the form of public meetings, which are chaired by the wojt or his deputy. Wojt organized the meeting, monitored the order, and kept minutes. In order for the decision to be made, the majority of those present at the meeting had to vote for it. As for the government of the public or the Starshyna, it had the executive power, and it was obliged to carry out everything that was decided by the Council, or what it considered appropriate within the competence. Thus, the Starshyna was forbidden to go beyond the 
powers established by public law and on the public Council's competence. In case of a misunderstanding with the Council, when the Starshyna was convinced that the Council's decision is illegal, such a contradiction was resolved by Starostwo or the Uyezd Council.

As for the head of the community - wojt - he was recognized as a guardian of good and order in the commune. The wojt was responsible for conducting all affairs of the stars Starshyna, implementing the decisions of the public Council and orders coming from the state authorities. Two jurors (assessors) assisted the wojt in his affairs, to whom the wojt entrusted, under his responsibility, the execution of a specific assignment.

Wojt was in charge of the public property, the use of public property, and peace and security in the commune. The resolution of issues within the public Council's competence was carried out by the wojt exclusively following the decisions made. Only in urgent matters, the wojy could make a decision on his own, but with its subsequent approval at the next meeting of the Council. The Starshyna performed his duties with the help of government officials, police officers, and public servants. If their joint efforts were not sufficient to enforce the decision, the wojt could ask for the Starshyna Council's assistance, which had to provide the gendarmes to carry out the orders.

Thus, the preliminary review shows that the sphere of administrative functions of the gmina, both own and delegated, was regulated in sufficient detail in the current legislation, general and special laws; its observance was ensured by multilevel control of public authorities. The purpose of this control, as the authorities noted, was to protect the interests of community members from orders and measures that could violate those interests.

It has been concluded that at first, the peasants did not realize the importance of the reforms that took place and were quite contemptuous of their newly acquired rights. However, over time, public councils proved their effectiveness in the early twentieth century, and in villages there was a struggle between different parties for the mandates of deputies, especially the position of wojt.

Keywords: wojt, land cadastre, gmina, competence, community, Council, Starshyna.

DOI: 10.33766/2524-0323.91.41-54

УДК 342.7

О. А. Любчик,

доктор юридичних наук, доцент,

професор кафедри державно-правових дисциплін

Луганського державного університету

внутрішніх справ імені Е. О. Дідоренка

(м. Сєвєродонецьк, Україна)

e-mail: lyubchikaa@gmail.com

iDhttps://orcid.org/0000-0002-8239-2129

\section{ПРАВОВИЙ ПРЕЦЕДЕНТ - ДЖЕРЕЛО ПРАВА В УКРАЇНІ: ТАК ЧІ НІ ?}

У статті досліджуються підходи до визначення змісту та правової природи правового прецеденту як джерела права у формальному розумінні та його можливість виконувати функції таких джерел в Україні. Аналізуються різні підходищодо визначення понять «джерела права», «форма права», «правотворчість», «нормативність», «судова практика».

Надаються конкретні пропозищії щодо зміни діючого законодавства.

Запропонований зміст та визначення терміна джерело права у формальному розумінні, обгрунтована теза про відсутність в Україні такого джерела права, як «правовий прецедент», та зроблений висновок про недоцільність і недоречність його використання в української правої системі в майбутньому. 